\title{
Basement-controlled the fault nucleation and architecture of Rio do Peixe Basin, Brazil
}

Gilsijane V. Ramos ${ }^{1}$, Francisco H. R. Bezerra², David L. de Castro², David L. Vasconcelos ${ }^{3}$, Francisco C. C. Nogueira ${ }^{3}$, Yoe A. Reyes ${ }^{2}$

1- Programa de Pós-Graduação em Geodinâmica e Geofísica

2- Departamento de Geologia - UFRN

3- Programa de Pós-Graduação em Exploração Petrolífera e Mineral - UFCG

Copyright 2021, SBGf - Sociedade Brasileira de Geofísica

This paper was prepared for presentation during the $17^{\text {th }}$ International Congress of the Brazilian Geophysical Society held in Rio de Janeiro, Brazil, 16-19 August 2021.

Contents of this paper were reviewed by the Technical Committee of the $17^{\text {th }}$ International Congress of the Brazilian Geophysical Society and do not necessarily represent any position of the SBGf, its officers or members. Electronic reproduction or storage of any part of this paper for commercial purposes without the written consent of the Brazilian Geophysical Society is prohibited.

\section{Abstract}

The Rio do Peixe Basin (RPB) is part of a set of aborted rifts with NE-SW trend along the NE region of Brazil. This research integrates aeromagnetic, gravity, and seismic data with geological field data to show that the reactivation of weak basement fabric in RPB represents an inheritance of the heterogeneous intrabasement deformation, influencing fault nucleation and basin architecture. Interpretation of geophysical data allowed the identification of ductile basement structures beneath RPB and the brittle reactivations along RPB. In the basement, the weak basement fabric was identified with magnetic lineaments associated with faults identified in seismic data. The continuation of magnetic lineaments into the basin represents faults associated with the basement reactivation in the basin. Normally, the nucleation of faults on pre-existing strength anisotropies influences the fluid circulation along these faults.

\section{Introduction}

The pre-existing structures on basement can influence a subsequent geological event (Phillips et al., 2019; Matos et al., 2021; Ramos et al., 2021) and has significant implications for fault development (Cowie et al., 2000) in sedimentary basins. Heterogeneities inherited from orogenic events control the tectonic processes (Naliboff and Buiter, 2015; Phillips et al., 2019), as zones of structural weakness in the basement, locating the tectonic reactivation (Kolawole et al., 2018, 2020) and shaping the rift architecture and localization (Vasconcelos et al., 2019b; Ye et al., 2020; Strugale et al., 2021).

Studies regarding pre-existing structural elements and the mechanisms that controlled the continental breakup are crucial to understanding the rift evolution (Phillips et al., 2016; Peace et al., 2018; Schiffer et al., 2019). Researches in extensional rift fault geometry demonstrating the reactivation of weak fabric and how this influence happens and control the location of basin depocenters are still scarce as a result of there is reactivation on various scales and at different depths within the crust (Holdsworth et al., 2001; Kirkpatrick et al., 2013; Phillips et al., 2019; Vasconcelos et al., 2019a).

Geophysical data is fundamental for the Precambrian basement geological structures characterization of Brazilian sedimentary basins (de Castro et al., 2012; Jacques et al., 2014; Vasconcelos et al., 2019a,b). The integration of geophysical and geological data allows to differentiate geological boundaries (Oliveira and Medeiros, 2014) and identify the continuity of ductile structures beneath sedimentary basins (de Castro et al., 2012; Bezerra et al., 2014; Vasconcelos et al., 2019b). In this context, the use of geophysical methods (seismic, magnetic, and gravity) data in mapping geological/structural has become common in surveys of sedimentary basins in the NE of Brazil (e.g, de Castro et al., 2012; Andrades Filho et al., 2020; Bezerra et al., 2014; Jacques et al., 2014).

The main objective of this study is to show that the reactivation of weak basement fabric in Rio do Peixe basin (RPB) represents an inheritance of the heterogeneous intra-basement deformation, influencing fault nucleation and basin architecture. The research area is located in the central portion of the Borborema Province (BP), NE Brazil (Figure 1). The Rio do Peixe Basin (RPB) is an intracontinental rift basin, formed due to the brittle reactivation of the ductile, NE-striking Portalegre and E-W striking Patos shear zones, which generated the NE-striking Portalegre fault and the E-Wstriking Malta fault system, respectively (Figure 1), and effectively was installed during the Cretaceous event that defined the Brazilian equatorial margin. The RPB is situated in the BP, characterized by geological terrains of northeastern Brazil affected by the Neoproterozoic Brasiliano/Pan-African belts (750 to $540 \mathrm{Ma}$ ) (Almeida et al., 2000; Brito Neves et al., 2000). Three main domains compose the crystalline basement of the RPB: Granjeiro (GD), Orós-Jaguaribe (OJD), and Rio Piranhas (RPD) (Figure 1B). The Orós-Jaguaribe and Rio Piranhas domains are divided by the Portalegre Shear Zone, while the Malta Shear Zone defines the northern boundary of the Granjeiro domain (Figure 1B). The sedimentary 
deposits in the RPB are divided into five lithostratigraphic units from the base to the top: the Piloões/Triunfo, Antenor Navarro, Sousa, and Rio Piranhas Formations (Albuquerque, 1970). Furthermore, the RPB is separated by structural highs and form significant subsidence regions termed: Brejo das Freiras, Sousa, and Pombal (respectively BFSB, SSB, and PSB in Figure 1B) (Françolin et al., 1994; de Castro et al., 2007; Nogueira et al., 2015).

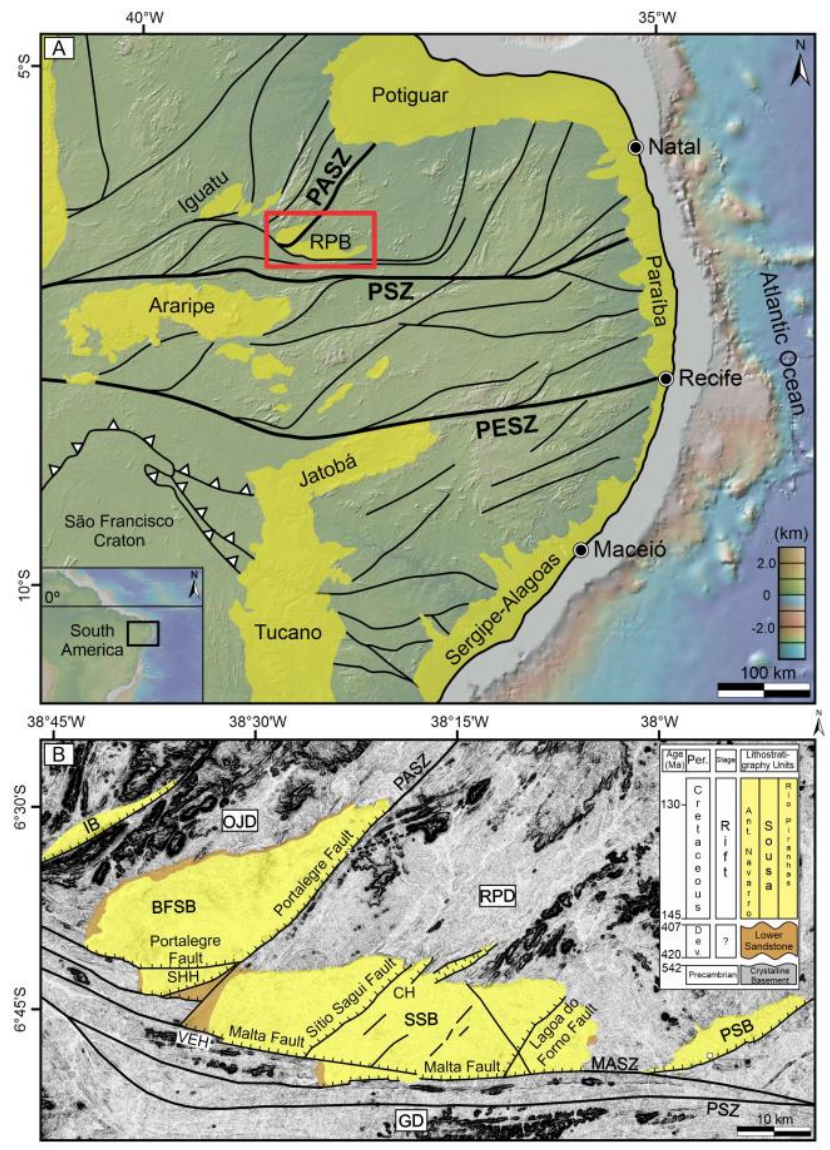

Figure 1. (a) Sedimentary basins (yellow area) and main shear zones (black lines) in NE Brazil. (b) The simplified geological structural map under slope image in the RPB area and stratigraphic chart of the RPB (modified from Vasconcelos et al., 2020). Domains: OJD, Orós Jaguaribe; RPD, Rio Piranhas; GD, Granjeiro. Basin and sub-basins: IB, Icozinho; BFSB, Brejo das Freiras; SSB, Sousa; PSB, Pombal. Basement horsts: SHH, Santa Helena; VEH, Varzea da Ema; $\mathrm{CH}$, Caicara. Shear zones: PASZ, Portalegre; PSZ, Patos; PESZ, Pernambuco

\section{Methods}

\section{Airborne magnetic data processing}

The airborne magnetic surveys were carried out by the Paraíba-Rio Grande do Norte and Pernambuco-Paraiba Geophysical Projects (MME/CPRM, 2010), sponsored by the Brazilian Geological Survey. The project raised highresolution magnetic profiles, with flight and control lines spaced of $500 \mathrm{~m}$ and $5000 \mathrm{~m}$, oriented in the N-S and E-
W directions, respectively, and with flight height set at 100 $\mathrm{m}$ above the ground. These surveys used the vapor sensor magnetometer cesium mounted on the tail of the aircraft (stinger type). The measurements are taken every 0.1 second. In addition, the aeromagnetic data were corrected for the transient geomagnetic variations and removed from the main geomagnetic field (International Geomagnetic Reference Field - IGRF).

\section{Seismic Reflection analysis}

Seismic reflection data include eight 2D seismic sections and three 3D seismic surveys, both previously stacked and migrated in time by the Brazilian Agency of Petroleum, Natural Gas, and Biofuels (ANP). Both 2D and 3D seismic data are exhibited with reverse polarity (SEG convention) so that a red reflection on seismic sections agrees to a positive polarity, whereas a blue reflection on seismic sections agrees to a negative polarity.

\section{Magnetic Processing Flowchart}

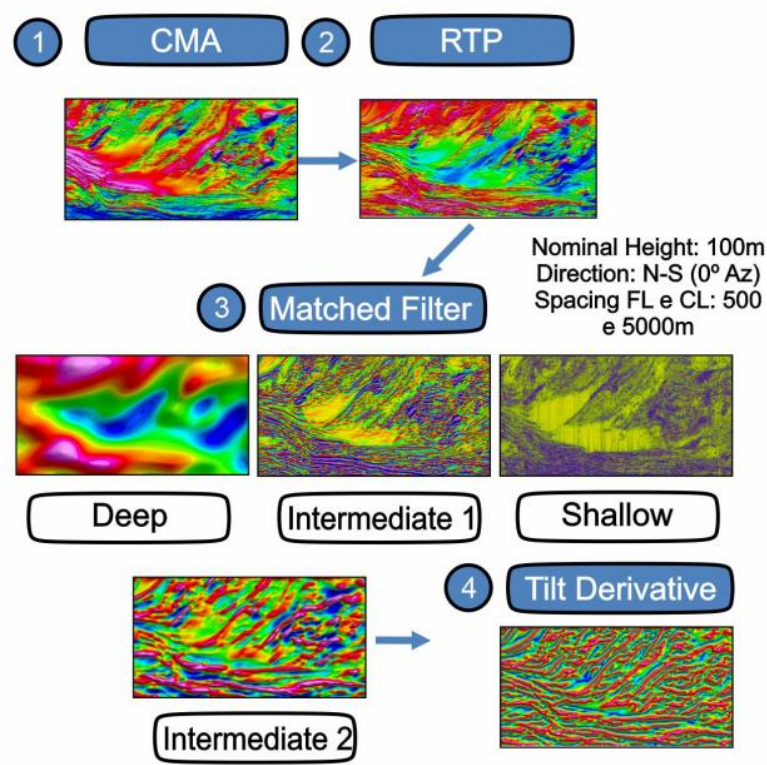

Figure 2. Aeromagnetic data processing step.

\section{Results \\ Magnetic signatures of the $R P B$}

The investigations were concentrated on the identification of shear zones such as the Malta and Portalegre shear zones (Figure 1B). The Precambrian basement includes three tectonic domains: Granjeiro, Orós-Jaguaribe, and Rio Piranhas (respectively GD, OJD, and RPD in Figures $1 \mathrm{~b}$ and 3). The TDR-INT2 map was the main magnetic image used to interpret the magnetic lineaments (Figures $3 \mathrm{~A}$ and $3 B$ ). This map highlights NE and $E-W$ lineaments in the RPB, associated with the main trend of ductile shear zones existing in the study area, probably related to the Portalegre and Malta shear zones reactivation outcropping in the RPB. 
The magnetic lineaments' rose diagrams (Figure 4) display the two structural trends: NE and E-W. The E-W direction in the GD (Figure 4A) and the SSB (Figure 4E). Secondarily, the GD exhibits NE lineaments in areas to the north. In contrast, NE lineaments are mainly observed in the OJD, RPD, BFSB, and PSB (Figures 4B, 4C, 4D, and 4F). It is possible analyze that the magnetic anomalies coincide with the mapped crystalline basement shear zones and with the mapped faults in the sedimentary basin. From that, it is suggestive that the faults are brittle shear zones reactivations.

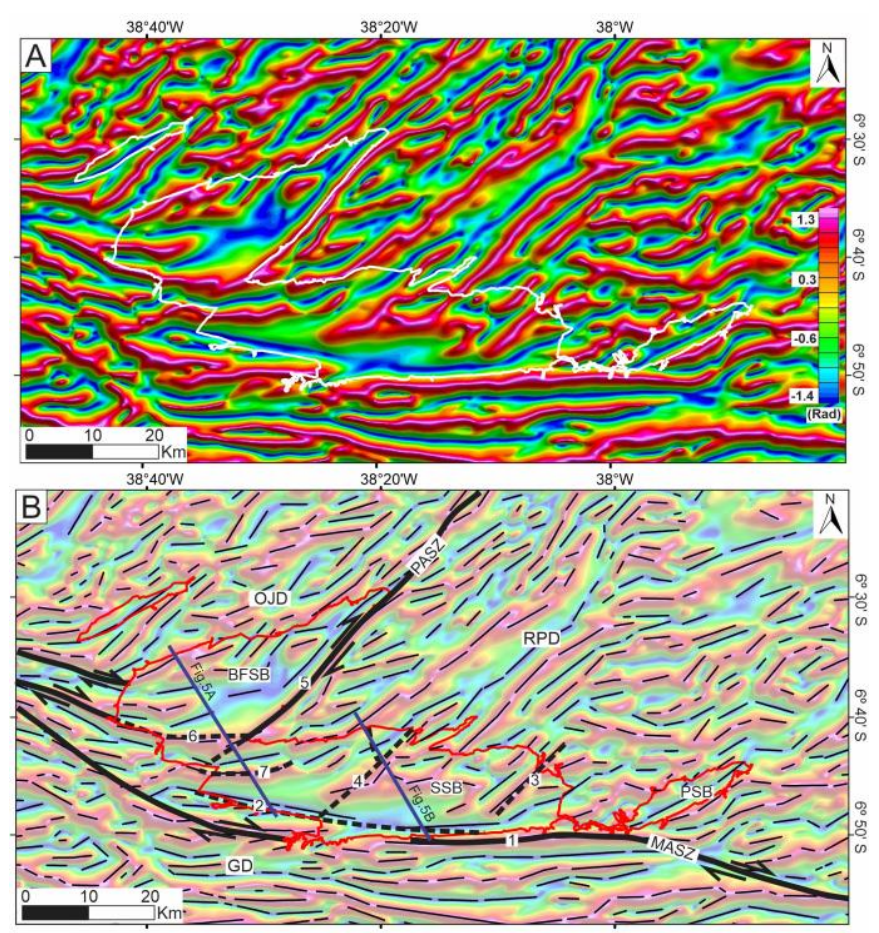

Figure 3. Magnetic map of the RPB. (A) Tilt-Derivative of Intermediate 2 magnetic map; $(B)$ interpreted magnetic lineaments. Domains: OJD - Orós-Jaguaribe; RPD - Rio Piranhas; GD - Granjeiro. Shear Zones: PASZ Portalegre; MASZ - Malta. Sub-basins: BFSB - Brejo das Freiras; SSB - Sousa; PSB - Pombal. Number 1 to 7 Magnetic anomalies corresponding to faults.

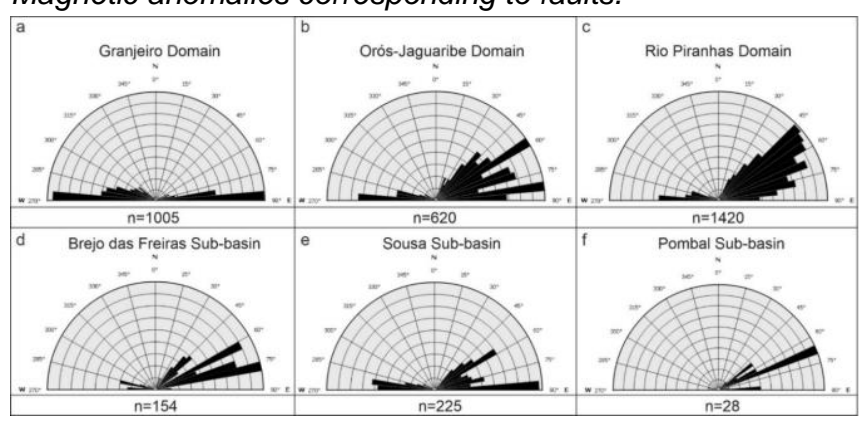

Figure 4. Rose diagrams of the magnetic lineaments of the Rio do Peixe basin. $n=$ Lineaments quantity.

Magnetic and seismic evidence of the basin geometry
Using filtered magnetic anomalies (Figure 3), the superficial expressions of the Rio do Peixe basin fault segments were mapped. On seismic data, we initially separated two seismic stratigraphic sequences for this study: (pre-rift and rift). Besides, we mapped the basement top and traced major faults (Figures 5A and 5B). We compared the magnetic anomalies and the internal basin architecture along the seismic profiles. Moreover, we analyzed that the deformation does not concenter individual along the weakness zones from the ductile shear zones that influenced the formation of the basin boundary faults in the RPB (e.g., Portalegre and Malta faults). The Precambrian Basement is mainly recognizable through chaotic reflectors. The change from chaotic to low amplitude reflectors marks the transition from the Precambrian Basement to the Lower Sandstones, which records a moderate acoustic impedance contrast. It is the most important feature of the contact between these units in the RPB.

In the fieldwork, were possible observe Lower Sandstones outcropping in the Santa Helena (Figure 5a) and Varzea da Ema horsts, and along most of the flexural borders of the RPB (Figure 1b). The contact between Lower Sandstones and Rift sequences in the seismic sections is emphasized by the strong acoustic impedance between these two units due to the different amplitudes of the reflectors (Figures 5a,b): low amplitude reflectors in the Lower Sandstones, and high amplitude in the Rift Sequence.

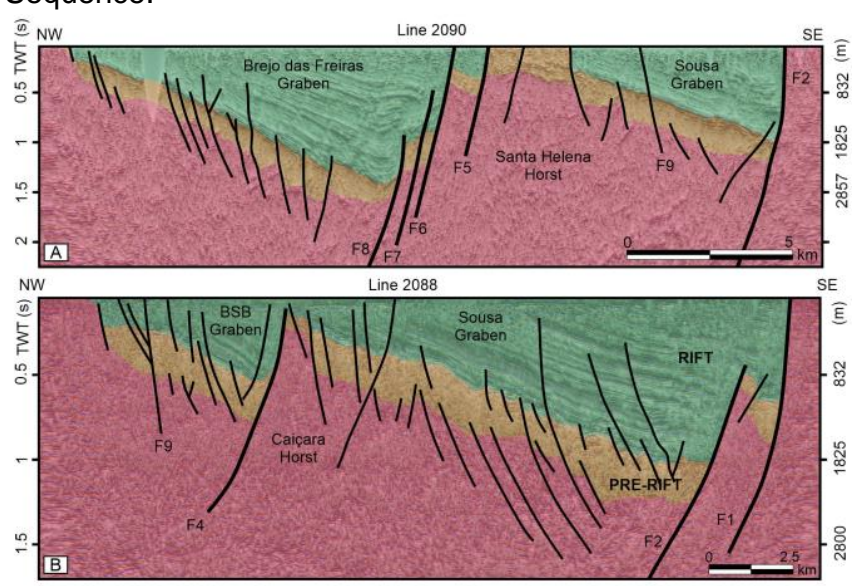

Figure 5. (A) $2 D$ seismic line 2090 interpreted. (B) $2 D$ seismic line 2089 interpreted.

\section{Conclusions}

Here, we characterized the intra-basement structures of the Precambrian basement of the Rio do Peixe Basin, Brazil and investigated how the brittle component of the basement structure is inherited by the overlying sedimentary sequences. We planned the basement surface's geophysical modeling and associated it with controlling factors to a reservoir formation. Furthermore, 
we can comprehend the main pre-existing structures that accommodated the Precambrian deformation until the present.

The magnetic maps contributed to a better characterization of the crystalline basement fabric, which is mainly composed of metamorphic foliations, and its interpretation enabled the selection of potential areas for shear zones brittle reactivations in RPB. Inside the basin were visualized brittle reactivations, with preferential directions NE-SW in sedimentary sequences. The seismic section interpretations were important to associate the basement structures displayed on magnetic data with structures found within RPB. The interpretation of the same data, integrated with regional geological knowledge, was essential to check the reactivations. Finally, it is recommended the use of geochronological data regarding the brittle reactivations, mainly with integrated with seismic data.

\section{Acknowledgments}

We thank the Geological Survey of Brazil (CPRM) for providing aerogeophysical projects and the Brazilian Agency of Petroleum, Natural Gas and Biofuels (ANP) for providing seismic reflection data through protocol number 9934 (Shipping Bulletin 11446) of October 02, 2019. We acknowledge Schlumberger for the provision of Petrel software licenses to the Federal University of Campina Grande. We acknowledge the DEBRIP Project (Process 2017/00767-0 SAP 4600579230), funded by Petrobras in cooperation with the Federal University of Campina Grande. GVR thanks CNPq for its doctoral scholarship.

\section{References}

Albuquerque, J.P.T., 1970. Inventário hidrogeológico básico do Nordeste, Folha 15, Jaguaribe-SE. Recife.

Almeida, F.F.M. De, Brito Neves, B.B. De, Dal Ré Carneiro, C., 2000. The origin and evolution of the South American Platform. Earth-Science Rev. 50, 77-111. https://doi.org/10.1016/S0012$\underline{8252(99) 00072-0}$

Andrades-Filho, C. O., Rossetti, D. de F., Bezerra, F.H.R., 2020. The unsteady post-rift stage of the South American passive margin based on the tectono-sedimentary evolution of the onshore Paraíba Basin, NE Brazil. Quat. Int. https://doi.org/10.1016/j.quaint.2020.10.051

Bezerra, F.H.R.; Rosseti, D.F.; Oliveira, R.G.; Medeiros, W.E.; Neves, E.B.; Balsamo, F.; Nogueira, F.C.C.;
Dantas, E.L.; Andrades Filho, C.; Góes, A.M. 2014. Neotectonic reactivation of shear zones and implications for faulting style and geometry in the continental margin of NE Brazil. Tectonophysics (Amsterdam), 614, 78-90.

Brasil. MME/CPRM, 2010. Relatório final do levantamento e processamento dos dados magnetométricos e gamaespectrométricos. Paraíba - Rio Grande do Norte - Pernambuco Paraíba.

Brito Neves, B. B., Santos, E. J., and Van Schmus, W. R. (2000). Tectonic history of the Borborema Province, Northeast Brazil. U. G. In Cordani, A. Thomaz Filho, and D. A. Campos (Eds.), Tectonic Evolution of South America. Rio de Janeiro, 31STIGC, 151-182.

Cowie, P.A., Gupta, S., Dawers, N.H., 2000. Implications of fault array evolution for synrift depocentre development: Insights from a numerical fault growth model. Basin Res. 12, 241-261. https://doi.org/10.1111/j.1365-2117.2000.00126.x

de Castro, D.L., Oliveira, D.C., Castelo Branco, R.M.G., 2007. On the tectonics of the Neocomian Rio do Peixe Rift Basin, NE Brazil: Lessons from gravity, magnetics, and radiometric data. J. South Am. Earth Sci. 24, 184-202.

de Castro, D.L.; Bezerra, F.H.R.; Sousa, M.O.L; Fuck, R.A., 2012. Influence of Neoproterozoic tectônica fabric on the origin of the Potiguar, northeastern Brazil and its links with West Africa based on Gravity and Magnetic Data. Journal of Geodynamics, v. 52, p. 29-42.

Françolim, J.B.L., Cobbold, P.R., Szatmari, P., 1994. Faulting in the Early Cretaceous Rio do Peixe basin (NE Brazil) and its significance for the opening of the Atlantic. J. Struct. Geol. 16.

Holdsworth, R.E., Stewart, M., Imber, J., Strachan, R.A., 2001. The structure and rheological evolution of reactivated continental fault zones: A review and case study. Geol. Soc. Spec. Publ. 184, 115-137. https://doi.org/10.1144/GSL.SP.2001.184.01.07

Jacques, P.D.; Machado, R.; Oliveira, R. G.; Ferreira, F.J.F.; Castro, L.G.; Nummer, A.R. Correlation of lineaments (magnetic and topographic) and Phanerozoic brittle structures with Precambrian shear zones from the basement of the Paraná Basin, Santa Catarina State, Brazil. Brazilian 
Journal of Geology, v. 44, p. 39-64, 2014.

Kolawole, F., Atekwana, E.A., Laó-Dávila, D.A., Abdelsalam, M.G., Chindandali, P.R., Salima, J., Kalindekafe, L., 2018. Active Deformation of Malawi Rift's North Basin Hinge Zone Modulated by Reactivation of Preexisting Precambrian Shear Zone Fabric. Tectonics 37, 683-704.

Kolawole, F., Simpson Turko, M., Carpenter, B.M., 2020. Basement-controlled deformation of sedimentary sequences, Anadarko Shelf, Oklahoma. Basin Res. 32, 1365-1387.

Matos, R.M.D., Krueger, A., Norton, I., Casey, K., 2021. The fundamental role of the Borborema and BeninNigeria provinces of NE Brazil and NW Africa during the development of the South Atlantic Cretaceous Rift System. Mar. Pet. Geol. 104872. https://doi.org/10.1016/j.marpetgeo.2020.104872

Naliboff, J., Buiter, S.J.H., 2015. Rift reactivation and migration during multiphase extension. Earth Planet. Sci. Lett. 421, 58-67. https://doi.org/10.1016/j.epsl.2015.03.050

Nogueira, F.C.C., Marques, F.O., Bezerra, F.H.R., de Castro, D.L., Fuck, R.A., 2015. Cretaceous intracontinental rifting and post-rift inversion in NE Brazil: Insights from the Rio do Peixe Basin. Tectonophysics 644, 92-107. https://doi.org/10.1016/j.tecto.2014.12.016

Oliveira, R. G. e Medeiros, V. C. 2014. Aplicação de Dados Aerogamaespectrométricos e Aeromagnetométricos no Mapeamento da Faixa Dobrada Seridó (RN/PB) e de seu Embasamento. Serviço Geológico do Brasil - CPRM. Boletim SBGF - 88: 20-23.

Peace, A., McCaffrey, K., Imber, J., van Hunen, J., Hobbs, R., Wilson, R., 2018. The role of preexisting structures during rifting, continental breakup and transform system development, offshore West Greenland. Basin Res. 30, 373-394. https://doi.org/10.1111/bre.12257

Phillips, T.B., Fazlikhani, H., Gawthorpe, R.L., Fossen, H., Jackson, C.A.L., Bell, R.E., Faleide, J.I., Rotevatn, A., 2019. The Influence of Structural Inheritance and Multiphase Extension on Rift Development, the NorthernNorth Sea. Tectonics 38, 4099-4126. https://doi.org/10.1029/2019TC005756

Phillips, T.B., Jackson, C.A.L., Bell, R.E., Duffy, O.B.,
Fossen, H., 2016. Reactivation of intrabasement structures during rifting: A case study from offshore southern Norway. J. Struct. Geol. 91, 54-73. https://doi.org/10.1016/j.jsg.2016.08.008

Ramos, G. V., de Castro, D.L., Bezerra, F.H.R., Ferreira, J.M., do Nascimento, A.F., de Oliveira, P.H.S., Nogueira, F.C.C., 2020. Seismicity in the equatorial margin of Brazil reactivates the Precambrian basement fabric. J. South Am. Earth Sci. 106, 103084.https://doi.org/10.1016/j.jsames.2020.1030 84

Schiffer, C., Peace, A., Phethean, J., Gernigon, L., McCaffrey, K.E.N., Petersen, K.D., Foulger, G., 2019. The jan mayen microplate complex and the wilson cycle. Geol. Soc. Spec. Publ. 470, 393-414. https://doi.org/10.1144/SP470.2

Strugale, M., da Silva Schmitt, R., Cartwright, J., 2021. Basement geology and its controls on the nucleation and growth of rift faults in the northern campos basin, offshore brazil. Basin Res. 0-3. https://doi.org/10.1111/bre.12540

Vasconcelos, D.L., Bezerra, F.H.R., Clausen, O.R., Medeiros, W.E., de Castro, D.L., Vital, H., Barbosa, J.A., 2019a. Influence of Precambrian shear zones on the formation of oceanic fracture zones along the continental margin of Brazil. Mar. Pet. Geol. 101, 322-333.

Vasconcelos, D. L., Bezerra, F. H. R., Medeiros, W. E., de Castro, D. L., Clausen, O. R., Vital, H., \& Oliveira, R. G., 2019b. Basement fabric controls rift nucleation and postrift basin inversion in the continental margin of NE Brazil. Tectonophysics, $751,23-40$.

Vasconcelos, D.L., Marques, F.O., Nogueira, F.C.C., Perez, Y.A.R., Bezerra, F.H.R., Stohler, R.C., Souza, J.A.B., 2020. Tectonic inversion assessed by integration of geological and geophysical data: The intracontinental Rio do Peixe Basin, NE Brazil. Basin Res. 1-24.

Ye, Q., Mei, L., Shi, H., Du, J., Deng, P., Shu, Y., Camanni, G., 2020. The Influence of Pre-existing Basement Faults on the Cenozoic Structure and Evolution of the Proximal Domain, Northern South China Sea Rifted Margin. 